\section{SEXUALITY IN THAI FOLK SONGS}

\section{Buaphan Suphanyot ${ }^{1}$}

\begin{abstract}
Combining fieldwork research with textual analysis, this paper investigates the role of traditional Thai folk songs in teaching sexuality and sex education in contemporary Thai society. Although this mode of teaching is not formally included in school curricula, folk songs have easily lent themselves to the role of education and the transmission of cultural values. They are filled with humour, easy to remember, and do not challenge prevailing Thai moral standards. This paper shows how folk songs have long been an important way for Thai people to learn about sexual desire, the functioning of sexual organs, intercourse, sexual behaviour, courtship and reproduction, as well as the roles of husband and wife in marriage. Through a close reading of their musical composition, lyrics and symbols, the paper analyses the double role of folk songs in the transmission of knowledge about sex and the sexual body, as well as strengthening the notion of an essential Thai sense of aesthetics and way of life.
\end{abstract}

\section{Introduction}

Sex education has been strongly criticized by many Thai people, especially in the wake of the recent publication of the teenagers' handbook, "Khu Mue Wai Sai", issued in 2002 by the Office of the Permanent Secretary to the Prime

${ }^{1}$ Lecturer at School of Humanities, The University of the Thai Chamber of Commerce
Minister's Office. Some have claimed sexuality should not be openly discussed in Thai society since it is against the country's traditional moral standards.

According to many academics, Thai people suffer from a collective repression in matters of sexuality, and this is evidenced in the school curriculum. It was not until 1978 that sex education was first introduced to the secondary school curriculum. In 1990, the curriculum regarding sex education was revised as part of health education. Its content was focused primarily on broad health-related issues, such as changes to teenagers' emotions and personality, family planning, social behaviours, growth and sexual development, to name a few (Aimpradit et. al. 1997).

Thus, it can be said that the content of sex education in school curriculum is not fully adequate to the needs of Thai students. This view is also supported by the comment made by Mr. Sutham Saengpratum, the late Minister of Education. He argues that wide-ranging improvements need to be made to sex education, particularly in terms of teachers and learning methods.

Historically, sex education in Thailand was not promoted or formally taught in schools as it was in neighbouring countries like China, India, or Japan. This may be due to the fact that most Thai people are Buddhists, and thus obsessive sexual desire is culturally proscribed (Areephak and Areephak 1982). Consequently, Thai parents tend not to teach sexuality to their children, either in theory or practice (Boonperm 2001). Then it comes to the question of how sexuality was taught in the past. 
Sexuality is natural to both males and females. Nevertheless, it is still secret to many, and sexual discussion in public is taboo. Thai writers in the past were keen to present sexuality to their readers in a very aesthetic way. This can be seen from the large number of sexual scenes presented in some Thai literary works. Amatayakul (1984) investigated sexual relationships in literature of the Ratanakosin Period and revealed that sexual scenes in Thai literature were described in an ingenious way, mostly through metaphoric allusions to natural phenomena. Readers have to use their own imagination to understand what is occurring in the scenes, and this depends on the readers' own experience, linguistic ability, and background knowledge.

Sexuality is depicted not only in written literature but also in oral literature, particularly in traditional Thai repartee, a kind of Thai folk song. Sutchaya (2000) carried out a study of Thai repartees and concluded that sexuality played a vital role. According to Thai folklore, sexuality is closely related to fertility, which can be seen from a number of ritual practices and through the use of symbolic objects and expressions. Psychologically, repartees are also used as a means to express or release sexual drives in Thai society. This helps explain why a large number of taboo or obscene words can be found in repartees.

However, according to the available information, none of the research recognizes that sexuality in Thai folk songs can be considered as "knowledge" which Thai people ingeniously use to communicate to younger generations.

\section{Aims and Scope of the Study}

This paper aims to study the role of Thai folk songs as an indirect way to teach sexuality and sex education to the public.

The data used in this study are traditional Thai repartees, a type of Thai folk songs performed in the Central Region of Thailand. The informants are the late Mr. Klaiy Saengsri, Mrs. Buaphan Chansri, the late Mr. Somboon Suphanyot, and Mrs. Phuean Suphanyot

The data is from both primary and secondary sources, and they can be classified into 2 groups:

1. One hundred and fifty pieces of Pleng Rua or Boat Songs, folk songs performed in a boat at the end of a rainy season.

2. Four hundred and ninety-eight pieces of Pleng Choy, folk songs performed on the ground all year round.

\section{Definitions}

Sex education: The term is defined as the study of human sexuality.

A folk song: In this study, the term is specifically referred to repartees performed by men and women. The lyrics are mainly about courtship and sexuality which are indirectly presented through the use of erotic words. There are two types of erotic words as follows: Klon Daeng (direct erotic words) and Klon Song Ngae Song Ngarm (ambiguous erotic words). 


\section{Thai Folk Songs: An Indirect Way to Teach Sexuality}

According to the informants, folk songs were popularly performed in all festive seasons and were part of the Thai way of life. Teams of males and females, sometimes from different villages, competed with each other. Witty expressions were exchanged during the play. The main purpose of the folk songs was for entertainment, but they were used in contexts where courtship and love might develop. Thus, it can be seen that folk songs played a potentially important role in courtship and marriage among Thai men and women in the past. In addition, folk songs were widely used as a means to criticize and reflect what has been going on in Thai society. Most importantly, Thai folk songs help conserve Thai culture and transmit "knowledge" to the next generation in both direct and indirect ways.

Based on an analysis of the content of the folk songs used in this study, sexuality and sex education are indirectly taught as follows:

1. Physical change and sexual desire

2. Sexual organs and behaviours

3. Birth

4. Courtship

5. Spouse selection criteria

6. Roles and responsibilities of husbands and wives

7. Marital problems and solutions

\section{Physical Change and Sexual Desire}

A number of folk songs mention physical change in both men and women as follows:
Example 1

\section{“ด้วยว่าน้องเป็นสาวหน้าขาวนมขึ้น}

"Since you're a grown-up girl with bosoms,

เนื้อเหลืองนมลื่นน่าอาลัย

Your flesh and bosoms are so loving.

ส่วนตัวของพี่นี้ก็เป็นหนุ่ม

I'm also a grown-up boy,

เดือยกำลังตูมขึ้นมาใหม่ใหม่"

My penis size is growing bigger."

\section{$\underline{\text { Example 2 }}$}

\section{“มันเกิดผิดสำแดงปลายแกว่งชูโด่}

"It turns to be painful with a rigid erection

หาวเรอพุงโรไม่สบาย

And causes discomfort in my abdomen.

จะนอนตะแคงก็ตำกกขา

It's hard to lie down on my side as it hurts my inner thighs.

\section{นอนหงายชี้ฟ้าแดงยังดุ้นไฟ"}

But if I lie down on my back, it points straight up and is as red as fire."

(Excerpted from Pleng Choy, performed by Klaiy Saengsri)

From the examples above, it is clear that folk songs help teach Thai teenagers how their bodies have physically changed due to their awakening sexuality (Areephak and Areephak 1982). 


\section{Sexual Organs and Behaviours}

In folk songs, sexual organs and behaviours are generally compared to household objects or nature. For example, male sexual organs are compared to a banana or a pestle, while female sexual organs to a mortar or a turtle. Sexual activities are also compared to grounding a mortar with a pestle and many other actions with in-and-out movements.

\section{Example 3}

“พี่มีกล้วยน้ำว้าติดมาลูกเดียว

"I have just only one banana with me.

เปลือกก็แห้งลูกก็เหี่ยวจริงพับผ่า

Its skin is dry and the flesh inside is also drooping.

กะรอกมันแทะจนเปลือกแยะถลอก

A squirrel bit my banana, so the skin was torn open.

\section{มันไม่มีเปลือกหุ้มปลายปลอกหรอกหนา"}

It's really the banana without the skin at the end."

(Excerpted from Pleng Choy, performed by Klaiy Saengsri)

\section{Example 4}

\section{“อีกมือหนึ่งดึงถกผ้า}

"With one hand pulling out the cloth,

มือซ้ายก็คว้าฝาละมี

My left hand reaches your lid.

แต่ยาของพี่มันยาแท่ง

But my herbal medicine stick is a real stick.

ยาของฉันมันก็แข็งสิ้นดี
And my stick is really hard.

เลยคว้าดุ้นยาเข้าฝนฝน

So it's better to grind my herbal stick with your lid.

ฝนฝนแล้วก็วนฝาละมี

I go round and round on your lid.

ฝนริมทิ่มกระฉูดดูดไปกลาง

When I grind on the side, it pulls me into the center.

ฝาละมีดูดดังสิ้นดี"

My stick is sucked in so loud."

(Excerpted from Pleng Choy, performed by Klaiy Saengsri)

Folk songs also indicate how a virgin woman is different from a married one as illustrated in the following example.

Example 5

“ถ้ามีผัวแล้วก็ไม่แคล้วนมคล้อย

"If she has a husband, her bosom must be drooping.

หากเป็นสาวน้อยคงแน่นใน

If she is a virgin, she must be firm inside.

พิศดูหน้าก็ตก อกก็พร่อง

Her face is drooping and her bosom as well.

พิศดูผืนท้อง ให้สงสัย

Looking at her belly, I have doubts about it.

พิศดูตะโพก ทำไมตกตะพัก 
Looking at her hips, why are they wrinkled?

รอยใครเขาปักมาท้องลาย"

Who made those cracked lines on her belly?"

(Excerpted from Pleng Choy, performed by Klaiy Saengsri)

The above examples explain the way Thai people traditionally conceive the human body. They also reflect Thai values regarding virginity and how Thai women are taught to keep their virginity for their husbands.

\section{Birth of a Baby}

According to the data obtained, there is only one folk song that mentions the birth of a baby. Interestingly, the song was created a hundred years ago when modern medical science was not well known outside those who had studied abroad. The example below reveals the ingenuity of Thai songwriters of the past.

\section{Example 6}

“ตั้งเป็นตอก่อเป็นก้อน

"A limp is formed.

เกิดขึ้นมาก่อนเท่าลูกไข่ไก่

It is the same size as an egg.

เกิดจมูกขึ้นมาก่อน

A nose is then formed.

เกิดสมองอ่อนอ่อนกันเข้าไว้

It is formed together with a soft, soft brain. แล้วเกิดหน้าเกิดตาเกิดตัว
Then, a face and a body are formed.

เกิดหูเกิดหัวแขนขวาแขนซ้าย"

Followed by ears, a right arm and a left arm."

(Excerpted from Pleng Rua, performed by Somboon Suphanyot)

\section{Courtship}

In some folk songs, the lyrics reflect how relationships develop, beginning from "getting to know" until "knowing each other well". In Thai society, it takes time for a woman to accept a marriage proposal. Before getting married, a woman needs to know that her future husband is a good, patient, and sincere person.

\section{Example 7}

"ทุกวันพี่เที่ยวหานาง

"Everyday I go to see you

ไปเหมือนกวางหาหนอง

Just like a deer looks for a swamp.

ทุกวันพี่เที่ยวหาน้อง

Everyday I go to see my sweetheart

ไปเหมือนดงพรานหาเนื้อ

Just like a hunter looks for a deer.

\section{อีแม่คานน้อยของพี่หาบหนัก}

Oh my little darling, do you know how heavy the burdens on my shoulders are.

ไม่รู้เลยจะหักลงเมื่อเอ๋ยไร”

I still don't know when they're going to break down."

(Excerpted from Pleng Rua, performed by Somboon Suphanyot) 
Moreover, during the courtship, a man must be calm and patient. He must know how to say things properly, how to soothe his woman, and how to get along with her parents, among many other things.

\section{$\underline{\text { Example } 8}$}

"บอกว่าเขาว่าในตำราเขากล่าว

"The book says something

กันมาเป็นเรื่องราวจำไว้

That you should remember.

\section{ถึงว่าเจอสาวนี่แกต้องเล้าต้องโลม}

If you meet a woman, you need to be patient and talk to her politely and soothingly.

แกจะพูดจาหักโหมรู้ไหม

You are not allowed to talk to her ruthlessly.

จะมากินข้าวต้มกระโจมกลาง

It's just like you're having very hot rice porridge,

ว่าปากคอของแกจะพังรู้ไหม

It's going to burn your mouth.

ว่านิสัยจอดเรือมันต้องถึงตลิ่ง

It's just like you need to moor your boat on the shore.

ถ้าแม้นแกรักผู้หญิงถึงผู้ใหญ่"

If you love a woman, you need to ask her parents for permission."

(Excerpted from Pleng Rua, performed by Buaphan Chansri)
Even when a woman accepts a marriage proposal, it does not mean that a couple can have a sexual relationship whenever and wherever they want. A folk song also tells a couple to calm down because they are humans not animals. A sexual relationship before marriage is forbidden because the woman cannot lose her virginity or fall pregnant. A virtuous woman should save herself till the wedding ceremony. On the wedding night, the bride's parents will teach her how to look after her husband, particularly in regards to sexuality.

\section{Example 9}

“แม่จะสั่งแม่จะสอน

"As a mother, I'll tell you and teach you

ลูกเอ๋ยโอนอ่อนเอาใจ

You should take care and do whatever your husband needs.

ผัวเขาเรียกเอ็งต้องขาน

If he calls you, you must answer him.

ถ้าผัวเขาวานก็ต้องไป

If he asks you to do anything, you must do it.

แม้นว่าผิดไปบ้างพลั้งกันไปที

Sometimes things can go wrong.

ลูกเอ๋ยอย่าตีด้วยไม้

Be patient and never use violence.

ผัวหนักนิดเมียเบาหน่อยค่อยค่อยเถิดเจ้า..."

Compromising is what you should do." 
(Excerpted from Pleng Rua, performed by Buaphan Chansri)

From all of the examples mentioned above, it can be seen that a relationship between a man and a woman gradually develops. Both men and women are allowed to choose their own spouses but with the approval of their family. This also reflects the role of Thai family in teaching sexuality and sex education to their children.

\section{Spouse Selection Criteria}

Selecting the right spouse is a must in Thai society. A good spouse leads to a happy married life. Thai women must choose their husbands carefully regarding the following criteria: good health, good family background, good behaviour, good job, to name but a few.

\section{Example 10}

“คำหนึ่งก็เอาคำสองก็เล่น

“The first word, you say 'yes,'

The second word, you say you're kidding.

ถามว่าแกเอาเช่นมาจากไหน

Just want to ask where you've taken these words.

\section{คำหนึ่งก็รักสองคำก็รัก}

The first word, you say 'love.'

The second word, you also say 'love' again.

พี่จะมาพูดให้มากเกินไป

Is that too much to say?

วิสัยคบคนต้องดูหน้า
To make friends with someone, you need to look at their face.

วิสัยซื้อผ้าต้องดูลาย

To buy a piece of cloth, you need to look at the pattern.

ถ้าแม้นดีจะเอาเคียง

If he is good, I will accept him.

ถ้าไม่ดีจะเหวี่ยงทิ้งไป"

But if he is not good, I will throw him away."

(Excerpted from Pleng Rua, performed by Buaphan Chansri)

Some repartees also promote positive attitudes towards sexuality and married life. The following repartee says that having a good husband brings a happy married life.

Example 11

“มีผัวเปรียบเหมือนมีข้าว

"Having a husband is just like having rice at hand.

ถ้าหิวแล้วคิดเอากินก็ง่าย

If you are hungry, you can easily have it.

\section{นึกว่าแบ่งบึงให้พี่ปลูกบอน}

Just think that you share your swamp with me to nurture my root.

แต่พอแตกใบอ่อนแล้วจะไป"

When the new leaves come out ..."

(Excerpted from Pleng Choy, performed by Klaiy Saengsri) 
Additionally, some repartees assert that sexual relationships should depend on individual volition and consent.

\section{Example 12}

\section{“ถ้าอยากมีผัวแม่ก็เอง}

"If you want to have a husband, please do so.

\section{ใครจะเป็นเจ้าหัวใจ}

Who's going to own your heart?

\section{ถ้าอยากมีผัวแม่ก็มี}

If you want to have a husband, please do so.

ใครจะเป็นเจ้าโยนีของนางใน"

Who's going to own your vagina?"

(Excerpted from Pleng Choy, performed by Phuean Suphanyot)

To sum up, the examples mentioned above reflect the Thai way of life where the young should listen to, and behave themselves according to what they have been taught by, the old. Getting married is an important step in their life, so they should approach it prudently. Interestingly, the young are free to choose their own partner based on the criteria passed on to them through Thai folk songs.

\section{Roles and Responsibilities of Husbands and Wives}

To lead a happy married life does not depend on a sexual relationship alone, roles and responsibilities of husbands and wives must be considered as well. Many folk songs teach that a wife must be diligent, take care of her husband's parents and relatives, among other duties, which are in accordance with the Buddhist way of practice. His Honorary Somchai Dhanawutdho (2005) states that a good husband must respect his wife, never look down on her, never cheat on her, treat her as the master of the house and provide her with appropriate clothes. As for a good wife, she should take care of all the house chores, look after the husband's parents and relative, never cheat on him, take care of the property, and be diligent.

\section{Example 13}

\section{“ผัวนั่งกินข้าวให้นั่งเฝ้าสำรับ}

"Take care of your husband while he's having his meal.

\section{ดูว่าจะหมดกับอะไร}

See what he's having with his rice.

ถ้าแม้นผักเผาให้เจ้าหั่นห้ำ

If it's grilled vegetables, cut them into pieces.

หั่นเสียเป็นคำคำได้จิ้มง่าย"

So it will be easy for your husband to eat."

(Excerpted from Pleng Choy, performed by Somboon Suphanyot)

\section{Marital Life Problems and Solutions}

To lead a happy married life is not easy. Many problems can occur such as financial difficulties, conflicts with relatives, but most importantly infidelity. A husband may have an extra-marital affair, as may a wife. Repartees teach Thai people how to cope with these problems. 
Example 14

“มาอื้อหึงชักจะตึงหน้า

"When you feel jealous,

ไม่เกรงว่าผัวจะร้องด่าออกไป

Cool down and never scold your husband.

แม่จะต้องเอาน้ำเย็นเข้าไปก่อน

Your kindness is like cold water to calm everything down.

แล้วค่อยเอาน้ำร้อนเข้าไป"

Then bring in warm water."

(Excerpted from Pleng Rua, performed by Buaphan Chansri)

This example explains how a wife can cope with her husband's unfaithfulness. According to His Honorary Rabaeb Chittayano (1994), to lead a happy married life, Buddhist couples should be patient, trustworthy, and devoted. Thus, infidelity is not appropriate. However, when it happens, a wife should be patient and calm. By so doing, the couple can help solve the problem and get through the hard times without breaking up.

\section{Conclusion}

In the past, the Thai way of life was much closer to nature. Thai people compared sexuality to nature and used this comparison together with their linguistic ability to create ingenious folk songs. Additionally, because most Thai people are Buddhists, overt sexuality is taboo. Therefore, folk songs were used as a means to release sexual drives, and at the same time to indirectly teach sex education to others.
To sum up, sexuality is an essential aspect of Thai folk songs. Lyrics are pointedly composed to give a clear picture concerning teenagers' physical maturation, sexual organs and desire, birth, courtship, spouse selection criteria, roles and responsibilities of husbands and wives, and marital life problems and solutions. The songs also reveal that Thai people place important values on love, family, and sexuality. As a form of communal entertainment, repartees indirectly teach sexuality and sex education to Thais. Most of all, folk songs were based on the Buddhist way of practice and in accordance with traditional Thai values.

\section{Acknowledgement}

I would like to thank Mr. Klaiy Saengsri, Mrs. Buaphan Chansri, Mr. Somboon Suphanyot and Mrs. Phuean Suphanyot for providing me with valuable data used in this study. I would also like to thank Mr. Panchai Poonwathu for his advice on lyric translation.

\section{References}

Aimpradit, Nonglug and others. 1997. Knowledge of Sexuality. Bangkok: Thammasat University Press. (In Thai)

Amatayakul, Poonpit. 1984. Sex in Thai Literature. Language and Culture 4, 2 (July - December 1984). (In Thai)

Areephak, Anek and Suwattana Areephak. 1982. Rean Roo Ruang Pes. Bangkok: Chulalongkorn University Press. (In Thai)

Boonperm, Paradee. 2001. Sex Education in Families with Adolescents. Graduate School, Khonkaen University. (In Thai) 
Chittayano, Rabaeb, His Honorary. 1994.

Nithatedhamma ( $2^{\text {nd }}$ Edition).

Bangkok: Office of Buddhism

Promotion in Thailand. (In Thai)

Dhanawutdho, Somchai, His Honorary. 2005. Mongkol Chivit: Thang Kao Naa. Bangkok:International Buddhism Club Printing Center. (In Thai)

Eiosriwong, Nithi. 2002. Wa Duay "Pes" Kwam Kid Tuaton and Akhati Tang Pes Woman Gay Sexuality and Kama. Bangkok: Matichon. (In Thai)

Khao Sod. August 4, 2004. (In Thai)

Matichon Soodsubda, 22, 1128 (April 1 7, 2002). (In Thai)

Na Thalang, Siraporn. 1994. Thai Study. Nonthaburi: Sukhothaithammathirath Universies. (In Thai)

Nawikkamun, Anek. 1984. Pleng Nog Satawat. Bangkok: Muang Boran. (In Thai)

Patrachai (Sutchaya), Sukanya. 1997. Dialogue Song: Thai Villagers' Song of Wit. Bangkok: Chulalongkorn University Press. (In Thai)

Phu-Ngamthong, Mayuree. 1990. Sexually and Healthy in Family. Bangkok: Ministry of Education. (In Thai)

Pra We Nee Phid Pra Phe Nee? Khu Mue Wai Tog Kra. Matichon Soodsubda, 22, 1120 (February 1 - 7, 2002). (In Thai)

Ramitanon, Chaladchai. 2002. Kwam Samphan Cherng Amnat Ying-Chai Phaiy Tai "Pra We Nee". Siam Rath Sabdaawijarn. 49, 24 (November 8 14, 2002), pp. 86 - 87. (In Thai)
Right, Michael. 2002. Khu Mue Wai SaiThai Pen Budh Rue Farang Gun Nae?.

Santasombat, Yos. 1997. Man and Culture. Bangkok: Thammasat University Press. (In Thai)

Sivalak, Suluk. 1995. Chariyatham Tang Pes Nai Songkhom Buddhism. Bangkok: Song Sayam Co.,Ltd. (In Thai)

Srisaeang-nam, Udomsilp and Surawan Worawan, M.R. 1987. Ku Mue Kan Son Ruang Khrob Khrua Suksa. Bangkok: The Planned Parenthood Association of Thailand under the Patronage of H.R.H. the Princess Mother. (In Thai)

Sutchaya, Sukanya. 2000. Thai Villagers's Song Studies. Bangkok: Chulalongkorn University Press. (In Thai)

The Planned Parenthood Association of Thailand under the Patronage of H.R.H. the Princess Mother. 1982. Sex Education. Bangkok: Odeon Store.

Wongthes, Pranee. 2001. Sex and Culture. Bangkok: Silpwattanatham Co.,Ltd. (In Thai)

http://thesis.tiac.or.th 